\title{
SISTEM INFORMASI AKADEMIK UNTUK PENJADWALAN MATA KULIAH DAN PENGISIAN KRS (KARTU RENCANA STUDI) PADA UNIVERSITAS MATANA
}

\author{
HIMAWAN \\ TIMOTHY RICHARD LEGIA \\ Program Studi Teknik Informatika \\ Fakultas Sains Teknologi dan Matematika, STMIK Raharja, Universitas Matana \\ Email: himawanawan10@gmail.com, timothyrichard7@gmail.com
}

\begin{abstract}
Abstrak. Permasalahan klasik yang cukup banyak dan sering ditemui pada hampir semua perguruan tinggi di Indonesia adalah pada saat penyusunan daftar mata kuliah yang rutin dilakukan pada setiap pergantian semester adalah penjadwalan mata kuliah dan juga pengisian Kartu Rencana Studi (KRS) yang dilakukan oleh para mahasiswa. Kendalakendala yang menyebabkan permasalahan tersebut dapat terjadi adalah dikarenakan faktor terbatasnya ruangan kelas (kelas teori dan lab praktikum), faktor rasio jumlah dosen dengan mahasiswa yang mengambil mata kuliah dan kemudian faktor ketersediaan dosen yang bisa mengajar untuk masing-masing mata kuliah yang ditawarkan oleh setiap program studi yang ada di Universitas Matana. Oleh karena faktor-faktor itulah yang membuat penyusunan daftar mata kuliah beserta dengan jadwal hari dan waktunya menjadi rumit dan tidak mudah untuk dilakukan, karena penyusunan jadwal mata kuliah yang optimal adalah untuk menghindari terjadinya ketidakcocokan atau bentrok antara jadwal 1 mata kuliah dengan mata kuliah yang lainnya. Melihat pada hal-hal tersebut, maka penelitian ini dilakukan untuk dapat merancang Sistem Informasi Akademik (SIAKAD) yang dapat membantu pihak BPAP dalam menyusun jadwal perkuliahan yang lebih cepat bagi setiap program studi yang ada di Universitas Matana agar dapat melihat sedari awal untuk jadwal-jadwal mata kuliah yang bentrok serta untuk pemetaan (mapping) mata kuliah pada slot waktu perkuliahan yang ada setiap harinya di Universitas Matana.
\end{abstract}

Kata Kunci: penjadwalan mata kuliah, KRS, sistem informasi akademik

\begin{abstract}
The classical problems are quite common and often found in almost all universities in Indonesia is at the time of preparation of the list of subjects that are routinely done at every turn of the semester is the scheduling of courses and also filling the Study Plan Card (KRS) conducted by the students. The constraints that caused the problem to occur were due to the limited factor of the classroom (theoretical class and lab lab), the ratio factor of the number of lecturers to the students taking the course and then the lecturer availability factor that could teach for each course offered by every course available at Matana University. Because of the factors that make the list of courses along with the schedule of the day and time becomes complicated and not easy to do, because the preparation of the optimal course schedule is to avoid the occurrence of incompatibility or clash between the schedule of 1 course with other courses . Looking at these things, this research is done to be able to design Academic Information System (SIAKAD) that can help the BPAP in preparing a schedule of lectures more quickly for each study program at the University of Matana in order to see early for schedules clashing courses and for mapping the courses in the lecture time slots that are available every day at Matana University.
\end{abstract}

Key words: courses scheduling, KRS, Academic Information Systems 


\section{PENDAHULUAN}

Kegiatan pembelajaran dalam dunia perguruan tinggi meliputi banyak hal, baik dari kegiatan yang bersifat akademik dan non-akademik. Kegiatan yang bersifat akademik meliputi kegiatan belajar mengajar yang di ikuti oleh para mahasiswa untuk mengikuti perkuliahan di kelas untuk mata kuliah yang bersifat teori ataupun di lab untuk mata kuliah praktikum, kemudian terdapat juga kegiatan para mahasiswa dalam mengikuti seminar ataupun workshop yang diselenggarakan oleh pihak kampus ataupun organisasi kemahasiswaan yang ada pada masing-masing kampus. Kegiatan-kegiatan tersebut dapat berjalan dengan baik dan lancar, tentunya tidak lepas dari pengelolaan atau sistem manajemen yang baik dari masing-masing pengelola kampus dan juga jajaran manajemen yang ada didalamnya. Berbicara mengenai sistem manajemen kampus, maka hal tersebut akan meliputi banyak sekali hal yang ada pada sebuah sistem yang ada di dalam perguruan tinggi. Di Indonesia sendiri terdapat beberapa tingkatan atau istilah yang digunakan untuk menyebut level dari sebuah perguruan tinggi yaitu akademi, sekolah tinggi, institut dan universitas. Walaupun memiliki istilah-istilah yang berbeda berdasarkan level tingkatannya, namun semuanya memiliki persamaan di dalamnya yaitu membutuhkan adanya pengelolaan atau manajemen yang baik agar sebuah perguruan tinggi dapat bertahan dan memiliki keberlangsungan yang bersifat kontinuitas dalam jangka waktu yang lama.

Bagi perguruan tinggi swasta yang sangat menggantungkan diri kepada para mahasiswa, maka mutu dan kualitas pelayanan kepada mahasiswa merupakan hal yang menjadi prioritas utama agar kegiatan perkuliahan dapat berjalan dengan baik dan optimal. Oleh karena itu diperlukan banyak hal untuk dapat mencapai hal tersebut, beberapa hal diantaranya adalah kualitas dosen yang baik, pelayanan ramah yang dilakukan oleh para staff akademik, fasilitas penunjang yang cukup, sistem manajemen kampus dan lain-lain.

Universitas Matana merupakan salah satu perguruan tinggi swasta yang berlokasi di daerah Gading Serpong Kota Tangerang yang masih berumur relatif muda (kurang lebih 4 tahun) dari sejak penelitian dan penulisan jurnal ini dilakukan. Di usianya yang relatif masih baru ini, pihak manajemen kampus menyadari bahwa keberlangsungan hidup universitas tidak hanya bergantung dari kualitas dosen, ketersediaan berbagai fasilitas kampus ataupun jumlah mahasiswa yang ada. Hal-hal tersebut memang penting, namun demikian apalah artinya jika hal-hal tersebut tidak didukung dengan sistem pengelolaan atau manajemen yang baik. Terlebih lagi jika sebuah kampus dengan tingkatan Universitas belum memiliki sebuah sistem yang dapat membantu pihak manajemen kampus Matana yang terutama dalam hal ini adalah para dosen, staf BPAP (Biro Pelayanan Administrasi Pembelajaran), ketua program studi, mahasiswa dan juga jajaran pimpinan kampus. Dengan adanya sistem informasi yang baik dan stabil maka kegiatan akademik dapat berjalan dengan lebih teratur, serta visi dan misi kampus Matana dapat tercapai.

Poin utama yang menjadi pembahasan dalam penulisan dan penelitian jurnal ini adalah akan membahas mengenai sistem manajemen kampus terutama pada sistem informasi akademik yang digunakan untuk mengatur pembuatan dan penyusunan jadwal perkuliahan yang berjalan pada setiap semesternya baik perkuliahan di semester ganjil maupun semester genap. Kemudian pembahasan berikutnya adalah memastikan bahwa jadwal yang telah disusun tidak terjadi benturan dengan jadwal mata kuliah lainnya. Pembahasan mengenai penjadwalan kuliah masih menjadi hal yang menarik untuk dilakukan, walaupun sudah terdapat banyak sekali pembahasan mengenai penjadwalan kuliah baik dalam bentuk laporan skripsi, paper conference dan jurnal. Hal tersebut dikarenakan walaupun sudah banyak sekali pembahasan yang dilakukan, namun setiap perguruan tinggi atau institusi memiliki kompleksitas atau permasalahan yang berbeda 
dengan perguruan tinggi lainnya, sehingga penelitian mengenai sistem penjadwalan perkuliahan masih mendapat perhatian dan porsi yang menarik baik dari kalangan akademisi dan juga praktisi.

Memang benar bahwa pembahasan-pembahasan yang telah dilakukan sebelumnya memiliki kesamaan antara satu dengan yang lainnya, hal ini dapat terlihat dengan jelas pada variabel-variabel yang digunakan pada bagian pembahasan permasalahan pada saat proses penjadwalan perkuliahan yaitu jumlah mata kuliah, jumlah ruangan yang tersedia, waktu perkuliahan, jumlah dosen yang mengajar dan jumlah mahasiswa yang mengambil mata kuliah. Di mana pada penelitian yang dilakukan oleh Firdaus (2017) dan juga Suhartono (2015) memfokuskan pada pengaturan jadwal kuliah berdasarkan slot waktu perkuliahan, ketersediaan ruangan kelas, jumlah dosen yang mengajar serta jumlah mahasiswa yang akan mengambil mata kuliah. Karena hal-hal tersebut akan mempengaruhi jumlah kelas yang akan dibuka oleh pihak BPAP pada semester yang baru nanti. Namun demikian, model sistem penjadwalan kuliah merupakan hal yang cukup rumit dan kompleks. Oleh karena itu pengaturan dan penyusunan jadwal perkuliahan pada setiap semester baru membutuhkan ketelitian, kecermatan, kecepatan dan ketepatan agar dapat menghasilkan jadwal mata kuliah yang optimal. Tanpa hal tersebut maka penyusunan jadwal mata kuliah akan menjadi kacau, kemudian terjadinya benturan jadwal mata kuliah yang satu dengan lainnya dan yang pada akhirnya jadwal pengisian KRS (Kartu Rencana Studi) yang akan dilakukan oleh para mahasiswa menjelang perkuliahan awal semester baru menjadi terhambat dan mundur dari waktu yang telah ditetapkan sebelumnya.

\section{METODE}

Metode penelitian yang digunakan dalam penelitian ini adalah berbasiskan action research di mana metode ini memfokuskan pada objek penelitian yang sedang diteliti, kemudian melihat dan juga menganalisa permasalahan yang ada pada sebuah penelitian (Olmo, 2016). Model penelitian berbasis action research memiliki tahapan-tahapan yang dimulai dari perencanaan (planning), pengamatan (observation), tindakan (action) dan hasil produk (reflection) (Olmo, 2016).

Kemudian pendekatan yang digunakan adalah menggunakan metode studi kasus (case study) pada Universitas Matana khususnya pada bagian BPAP, kemudian penggunaan metode analisis data (data analysis) berdasarkan data-data yang dikumpulkan peneliti dari pihak BPAP yang meliputi data mahasiswa, dosen, ruangan kelas perkuliahan, jadwal dosen, krs dan daftar mata kuliah. Sedangkan untuk teknik penyusunan dan jadwal perkuliahan yang akan digunakan dalam penulisan dan pembahasan sistem penjadwalan mata kuliah pada dokumen jurnal ini adalah dengan menggunakan SQL Optimizer (Query Optimization).

\section{Penelitian Terkait}

Penelitian-penelitian mengenai sistem pengaturan dan penjadwalan kuliah pada dunia perguruan tinggi seperti telah dituliskan dan dijelaskan pada bagian pendahuluan sudah banyak dilakukan. Di mana penelitian-penelitian tersebut menggunakan algoritma atau teknik yang berbeda untuk dapat menghasilkan sistem penjadwalan mata kuliah yang optimal, baik bagi para staff BPAP, para dosen serta mahasiswa yang akan melakukan kegiatan pengisian KRS pada setiap pergantian semester. Oleh karena itu peneliti merasa perlu untuk menuliskan beberapa penelitian terdahulu yang juga membahas sistem penjadwalan kuliah, namun penulisan penelitian terdahulu tersebut bukan dimaksudkan untuk melihat kekurangan atau bahkan keburukan dari penelitian yang telah dilakukan tersebut. Akan tetapi penulisan-penulisan penelitian-penelitian tersebut justru akan 
memperjelas letak (posisi) yang dilakukan oleh peneliti dengan peneliti lainnya dan melihat dari sudut pandang (perspektif) yang positif. Sehingga dapat menghasilkan sistem pengaturan dan penjadwalan perkuliahan yang lebih baik untuk dapat digunakan pada Universitas Matana dan berikut adalah beberapa penelitian terkait dengan menggunakan 3 metode atau algoritma yang berbeda, di mana penelitian-penelitian tersebut telah dikumpulkan oleh peneliti mengenai model sistem penjadwalan perkuliahan di perguruan tinggi:

1. Penelitian yang dilakukan oleh Adi Chandra Syarif dan Farid Hartono Gunawan (2014) dalam tulisan jurnalnya yang berjudul Penjadwalan Mata Kuliah Dengan Perampingan Algoritma Evolusi dan Pembobotan Distribusi Beban Kuliah, di mana pada penelitian ini dilakukan untuk melakukan pengaturan jadwal mata kuliah dan sesi perkuliahan. Penelitian ini dilakukan karena jadwal yang telah dihasilkan ternyata memiliki banyak permasalahan diantaranya adalah alokasi ruangan yang tidak sesuai dengan jumlah kelas yang dibuka untuk mata kuliah, selain itu terjadinya tabrakan antara waktu mengajar dosen dengan jadwal mata kuliah yang ditawarkan oleh pihak kampus. Penelitian ini menggunakan algoritma evolusi yang bertujuan untuk mengembangkan sebuah aplikasi yang dapat mengatur jadwal perkuliahan dengan optimal dan mengukur distribusi beban perkuliahan yang harus diambil oleh masingmasing mahasiswa pada setiap semesternya.

2. Penelitian yang dilakukan Theresia Sunarni, R. Kristoforus Jawa Bendi dan Achmad Alfian (2017) pada penulisan paper conference-nya yang berjudul Optimasi Penjadwalan Mata Kuliah Menggunakan Pewarnaan Graf, di mana pada penelitian ini membahas mengenai penyusunan jadwal mata kuliah yang dilakukan setiap semesternya dengan menggunakan slot waktu dan teknik pewarnaan graf menggunakan algoritma welch powell. Teknik tersebut digunakan untuk merepresentasikan verteks dan konflik yang terjadi jika terdapat jadwal yang bentrok antara 1 jadwal mata kuliah dengan mata kuliah yang lain di hari, ruangan dan interval waktu yang sama. Penelitian ini juga menjelaskan mengenai proses alokasi slot waktu dengan menggunakan 3 variabel yaitu perbedaan slot waktu yang tersedia, ruang yang tersedia dan juga hari yang tersedia untuk dibuatkannya jadwal mata kuliah yang akan diajar oleh dosen yang mengampu mata kuliah tersebut. Sedangkan hasil dari penelitian ini adalah untuk membuktikan bahwa penggunaan teknik pewarnaan elemen graf dapat menghasilkan penjadwalan mata kuliah yang optimal serta dapat memenuhi permintaan dari para dosen sesuai dengan hari dan waktu yang telah ditentukan sebelumnya oleh masing-masing dosen yang akan mengajar setiap mata kuliah.

3. Penelitian yang dilakukan oleh Akhmad Qashlim dan Muhammad Assidiq (2016) pada penulisan jurnalnya yang berjudul Penerapan Algoritma Genetika Untuk Sistem Penjadwalan Kuliah, di mana penelitian ini membahas pentingnya penjadwalan kuliah dikarenakan kegiatan penjadwalan merupakan hal yang dilakukan untuk mengatur serta mengalokasikan berbagai sumber daya yang nantinya juga akan menggunakan waktu serta sarana dan prasarana yang ada di lingkungan kampus seperti penggunaan ruangan kelas. Penggunaan algoritma genetika sangat banyak digunakan pada penelitian-penelitian yang membahas mengenai sistem penjadwalan mata kuliah dikarenakan penggunaan algoritma genetika jauh lebih baik dalam memecahkan permasalahan mengenai benturan waktu dan ruang pada sistem penjadwalan (Akhmad, 2016) (Fatma, 2014), di mana optimasi penggunaan algoritma genetika dapat menciptakan solusi yang optimal terhadap pengaturan jadwal penggunaan ruangan dan waktu. Penggunaan algoritma genetika yang menekankan pada 
penggunaan dan penyilangan kromosom sehingga menghasilkan mutasi kromosom baru untuk mendapatkan prosentase nilai fitness terbaik.

Dari ke-3 literatur review yang digunakan oleh peneliti dalam mempelajari mekanisme atau proses penjadwalan mata kuliah yang optimal, maka penggunaan algoritma-algoritma tersebut memiliki kelebihan dan kekurangannya masing-masing. Walaupun seperti yang telah dituliskan pada poin literature yang ke-3 di mana algoritma genetika merupakan algoritma yang paling populer dan banyak digunakan untuk mengatasi permasalahan mengenai penjadwalan penggunaan ruang dan waktu. Kemudian pada semua pembahasan literatur review tersebut juga menangani inti permasalahan yang sama yaitu mengoptimalkan keterbatasan jumlah ruangan kelas untuk pembagian alokasi waktu mengajar bagi para dosen agar tidak terjadi tumpang tindih jadwal mengajar dan kecepatan dalam penyusunan jadwal mata kuliah sehingga para mahasiswa Matana dapat melakukan pengisian KRS tepat pada waktunya.

\section{HASIL DAN PEMBAHASAN}

\section{Analisa Sistem Penjadwalan Perkuliahan Universitas Matana}

Universitas Matana telah mencoba untuk membuat sendiri Sistem Informasi Akademik (SIAKAD) sebanyak 3 kali. Di mana projek SIAKAD sendiri digagas oleh tim dosen pada program studi Teknik Informatika bersama dengan beberapa mahasiswa yang ada. Kemudian projek pertama dialihkan atau dilanjutkan kembali oleh tim yang berbeda, karena pada projek pertama mengalami kendala internal. Pada akhirnya sampai dengan pertengahan tahun 2017 pihak manajemen Universitas Matana memutuskan untuk membeli software atau aplikasi SIAKAD pada pihak ketiga, dikarenakan pengembangan dari tim internal membutuhkan waktu yang lama dan juga biaya yang tidak sedikit. Selain itu kendala sarana dari sisi infrastruktur yang belum cukup memadai membuat pihak manajemen kampus memiliki pertimbangan sendiri untuk memutuskan membeli aplikasi SIAKAD dari pihak luar. Namun demikian sampai dengan awal perkuliahan semester genap tahun akademik 2017/2018, Universitas Matana belum memiliki sistem informasi akademik yang digunakan untuk melakukan pengelolaan berbagai aktifitas kegiatan akademik dan non-akademik di kampus. Semua dilakukan secara mandiri oleh para staf BPAP mulai dari membuat kalender akademik, penginputan nilai, pengolahan data absen mahasiswa dan dosen (tetap dan tidak tetap), pengisian KRS, pembuatan dan pencetakan KRS, pembuatan KHS dan juga transkrip nilai mahasiswa. Namun demikian, hasil kerja keras dari para staff BPAP dengan keadaan yang minim masih mampu membuat agenda perkuliahan pada semesternya berjalan dengan baik dan lancar. Semua informasi yang dibuat dan disampaikan kepada para mahasiswa dapat tersampaikan dengan baik.

Berdasarkan hal-hal yang telah disebutkan dan dijelaskan secara singkat pada paragraf di atas, maka peneliti yang juga sekaligus dosen Teknik Informatika Universitas Matana berinisiatif bersama dengan beberapa rekan-rekan mahasiswa untuk kembali melanjutkan projek SIAKAD yang sempat tertunda selama beberapa waktu, dikarenakan projek SIAKAD ini akan sangat membantu banyak pihak dan juga dapat meningkatkan nilai akreditasi bagi setiap program studi yang ada di Universitas Matana. Seperti yang telah dituliskan pada bagian pendahuluan bahwa fokus penelitian pada penulisan jurnal ini akan berfokus pada sistem penjadwalan mata kuliah yang akan digunakan untuk pengisian KRS oleh mahasiswa Universitas Matana pada setiap semesternya, karena jika pembahasan SIAKAD dilakukan seutuhnya maka akan sangat kompleks sekali dan berkaitan dengan banyak hal yang membuat pembahasan akan menjadi lebih panjang.

Tahapan analisa sistem penjadwalan perkuliahan yang ada di Universitas Matana akan berdasarkan pada poin-poin batasan (hard constraints), di mana batasan tersebut 
terdiri dari kondisi, sifat dan kebutuhan yang telah ditentukan dan semaksimal mungkin dapat dipenuhi dengan sebuah solusi untuk menyelesaikan batasan-batasan masalah yang terjadi terkait dengan sistem penjadwalan perkuliahan di Universitas Matana. Berikut adalah poin-poin batasannya:

1. Setiap dosen tidak dapat mengajar untuk 2 mata kuliah yang sama atau berbeda pada hari, interval waktu dan ruangan yang sama.

2. Pada ruangan kelas yang sama hanya bisa diisi untuk 1 mata kuliah saja untuk interval slot waktu yang ada, misalnya ruangan L.201 pada jam 08.00 - 10.30 hanya bisa digunakan untuk 1 mata kuliah saja dan ruangan tersebut hanya bisa diisi atau digunakan untuk mata kuliah lain setelah periode waktu untuk mata kuliah sebelumnya telah berakhir.

3. Dosen tetap matana, terutama yang memiliki jabatan struktural tidak mengajar dihari rabu, karena hari tersebut akan digunakan untuk agenda rapat koordinasi antar divisi atau unit dan juga rapat senat.

4. Semua dosen tetap Matana untuk setiap program studi memiliki kewajiban atau beban mengajar minimal 9 sks.

\section{Variabel Penyusunan Jadwal Mata Kuliah Universitas Matana}

Permasalahan-permasalahan yang sangat krusial untuk diselesaikan pada setiap penyusunan jadwal kuliah menjelang dimulainya semester baru khususnya bagi pihak BPAP Universitas Matana adalah dengan melihat faktor-faktor umum yang telah disebutkan pada paragraf sebelumnya dan juga ditambahkan dengan faktor-faktor lain yang dapat mempengaruhi penyusunan jadwal mata kuliah untuk setiap program studi yang ada di Universitas Matana. Berikut ini adalah faktor-faktor utama yang menjadi poin penting dalam melakukan pengaturan dan pembagian jadwal mata kuliah yang dilakukan oleh pihak BPAP Universitas Matana:

1. Dosen, di mana pada Universitas Matana terdiri dari 2 status dosen yaitu dosen tetap dan dosen tidak tetap (part time).

2. Mahasiswa yang merupakan komponen utama pada saat melakukan pengisian KRS dan pembagian jadwal mata kuliah, kemudian mahasiswa matana juga terdiri dari mahasiswa regular (kelas pagi) dan mahasiswa karyawan (kelas malam).

3. Ruangan, di mana ruang-ruang kelas yang ada digunakan untuk ruang kelas teori dan juga digunakan untuk ruang kelas praktikum (lab komputer, studio foto, ruang desain arsitektur).

4. Waktu perkuliahan, untuk poin ini waktu perkuliahan yang ada di Universitas Matana di bagi menjadi 2 sesi waktu yaitu perkuliahan kelas regular (pagi) dan perkuliahan kelas karyawan (malam). Perkuliahan kelas pagi dimulai dari jam 8 pagi sampai dengan jam 5 sore, sedangkan perkuliahan kelas malam akan dimulai dari jam setengah 6 sore sampai dengan jam 10 malam. Perbedaan waktu kuliah tersebut akan menentukan dalam pembagian slot waktu mengajar bagi para dosen yang mengajar di kelas pagi atau kelas malam.

Berikutnya adalah faktor-faktor tambahan (soft constraints) yang menjadi perhatian dalam pengaturan dan pembagian jadwal perkuliahan menjelang dimulainya agenda perkuliahan pada semester baru. Di mana faktor-faktor berikut merupakan hasil pengamatan dan juga wawancara yang dilakukan oleh peneliti secara langsung selama mengajar di Universitas Matana dan juga hasil diskusi dengan pihak BPAP. Faktor-faktor tambahan tersebut akan dituliskan pada poin-poin berikut:

1. Tingkat prioritas dosen, pada poin ini tingkat prioritas dosen akan ditentukan berdasarkan status dosen tersebut. Di mana pada Universitas Matana terdapat 2 status 
dosen yaitu dosen tetap dan dosen tidak tetap. Terkait dengan status tersebut maka dosen dengan status sebagai dosen tidak tetap akan mendapat prioritas utama dalam hal pengaturan jadwal waktu mengajar. Hal tersebut dikarenakan terbatasnya waktu dosen yang bersangkutan, dimana alokasi hari dan waktu bagi dosen tidak tetap akan didahulukan untuk diatur penjadwalan mata kuliah dibandingkan dengan dosen tetap yang memiliki waktu lebih fleksibel terhadap kesediaan mengajar. Pada penelitian yang dilakukan oleh Suhartono (2015) menjelaskan bahwa tingkat prioritas dosen merupakan salah satu batasan dalam penyusunan penjadwalan mata kuliah yaitu soft constraint (diupayakan untuk terpenuhi) terutama bagi para dosen tidak tetap yang memang seperti telah dijelaskan sebelumnya yaitu memiliki keterbatasan waktu untuk kesiapan mengajar karena memiliki aktifitas atau kegiatan diluar kampus (praktisi).

2. Jumlah SKS, pada poin ini menjelaskan mengenai jumlah SKS maksimal yang dapat diambil oleh seorang mahasiswa untuk perkuliahan semester yang akan datang. Di mana ketentuan utama jumlah SKS maksimal yang dapat diambil adalah berdasarkan nilai IPS (Indeks Prestasi Semester) terakhir, karena di Universitas Matana sistem pemilihan mata kuliah adalah menggunakan model sistem paket baik untuk mata kuliah yang bersifat wajib diambil ataupun untuk mata kuliah pilihan.

3. Pemilihan waktu jadwal mata kuliah, dimana pemilihan waktu untuk jadwal mata kuliah di Universitas Matana akan melihat kepada jenis kategori dari mahasiswanya. Maksud dari kalimat ini adalah jika terdapat mata kuliah yang dibuka baik untuk kelas sesi pagi dan sesi malam, sedangkan mahasiswa yang ingin mengambil mata kuliah tersebut adalah mahasiswa kelas malam, maka mahasiswa tersebut tidak dapat mengambil jadwal mata kuliah yang dibuka pada waktu kelas sesi pagi.

Batasan-batasan yang akan menjadi fokus utama dalam penelitian dan penulisan dokumen jurnal ini adalah meliputi hal-hal berikut:

1. Penyusunan jadwal mata kuliah yang dilakukan tidak meliputi penyusunan jadwal ujian mahasiswa (UTS dan UAS).

2. Penyusunan jadwal mata kuliah juga tidak dilakukan pada saat perkuliahan yang berlangsung untuk periode semester pendek (SP). Hal ini dikarenakan rasio jumlah dosen dengan mahasiswa pada saat periode semester pendek masih sangat kecil (tidak mencapai 1:10), sehingga masih dapat dilakukan dengan proses penjadwalan biasa.

3. Halaman SIAKAD Matana belum dapat diakses secara online atau diluar dari lingkungan kampus Matana, karena aplikasi SIAKAD Matana masih bersifat intranet sehingga para mahasiswa Matana masih tetap perlu datang ke kampus untuk melakukan pengisian dan pencetakan KRS.

Pengembangan sistem informasi akademik yang dilakukan pada penelitian dan penulisan jurnal yang dilakukan oleh peneliti, jika dibandingkan dengan beberapa penelitian yang telah disebutkan dan dituliskan pada bagian sub-bab penelitian terkait akan dituliskan juga dalam bentuk tabel berikut ini : 
Tabel 1. Perbandingan Penelitian Sistem Informasi Akademik

\begin{tabular}{|c|c|c|c|c|c|}
\hline \multirow{2}{*}{$\begin{array}{c}\text { Nama } \\
\text { Penelitian }\end{array}$} & \multicolumn{5}{|c|}{ Variabel Penyusunan Jadwal Kuliah } \\
\hline & Mahasiswa & Dosen & Mata Kuliah & Ruangan & $\begin{array}{c}\text { Slot } \\
\text { Waktu }\end{array}$ \\
\hline $\begin{array}{l}\text { Optimasi } \\
\text { Penjadwalan } \\
\text { Mata Kuliah } \\
\text { Menggunakan } \\
\text { Pewarnaan } \\
\text { Graf } \\
\text { (Theresia } \\
\text { Sunarni, } \\
\text { 2017) }\end{array}$ & $\begin{array}{l}\text { Mahasiswa } \\
\text { hanya dapat } \\
\text { mengikuti } 1 \\
\text { perkuliahan } \\
\text { untuk 1 } \\
\text { lokasi di } \\
\text { waktu yang } \\
\text { sama }\end{array}$ & $\begin{array}{l}\text { Dosen yang } \\
\text { bersangkutan } \\
\text { tidak dapat } \\
\text { mengajar di } \\
\text { hari atau waktu } \\
\text { tertentu } \\
\text { (berdasarkan } \\
\text { permintaan) }\end{array}$ & $\begin{array}{l}\text { Penjadwalan } \\
\text { mata kuliah } \\
\text { menggunakan } \\
\text { identifikasi } \\
\text { dari } \\
\text { hubungan } \\
\text { antar verteks } \\
\text { yaitu waktu } \\
\text { mata kuliah } \\
\text { dan } \\
\text { kecocokan } \\
\text { jadwal } \\
\text { mengajar } \\
\text { dosen }\end{array}$ & $\begin{array}{l}\text { Terdapat } \\
\text { ruangan } \\
\text { khusus yang } \\
\text { digunakan } \\
\text { untuk mata } \\
\text { kuliah tertentu }\end{array}$ & $\begin{array}{l}24 \text { slot } \\
\text { waktu } \\
\text { untuk } \\
\text { perkuliahan } \\
\text { setiap } \\
\text { minggunya }\end{array}$ \\
\hline $\begin{array}{l}\text { Penerapan } \\
\text { Algoritma } \\
\text { Genetika } \\
\text { Untuk Sistem } \\
\text { Penjadwalan } \\
\text { Kuliah } \\
\text { (Akhmad } \\
\text { Qashlim, } \\
\text { 2016) }\end{array}$ & $\begin{array}{l}\text { Mahasiswa } \\
\text { hanya dapat } \\
\text { menghadiri } \\
\text { satu waktu } \\
\text { perkuliahan }\end{array}$ & $\begin{array}{l}\text { Dosen tidak } \\
\text { dapat mengajar } \\
\text { pada waktu } \\
\text { yang sama } \\
\text { walaupun } \\
\text { untuk mata } \\
\text { kuliah yang } \\
\text { berbeda }\end{array}$ & $\begin{array}{l}\text { Bobot mata } \\
\text { kuliah } \\
\text { menggunakan } \\
\text { sistem sesi } \\
\text { (dibagi } \\
\text { menjadi } 10 \\
\text { sesi) setiap } \\
\text { harinya }\end{array}$ & $\begin{array}{l}\text { Jumlah } \\
\text { ruangan yang } \\
\text { cukup akan } \\
\text { meminimalkan } \\
\text { terjadinya } \\
\text { constraint }\end{array}$ & $\begin{array}{l}40 \text { slot } \\
\text { waktu } \\
\text { untuk } \\
\text { perkuliahan } \\
\text { setiap } \\
\text { minggunya }\end{array}$ \\
\hline $\begin{array}{l}\text { Penjadwalan } \\
\text { Mata Kuliah } \\
\text { Dengan } \\
\text { Perampingan } \\
\text { Algoritma } \\
\text { Evolusi dan } \\
\text { Pembobotan } \\
\text { Distribusi } \\
\text { Beban Kuliah } \\
\text { (Adi Chandra } \\
\text { Syarif, 2014) }\end{array}$ & $\begin{array}{l}\text { Mahasiswa } \\
\text { mengikuti } \\
\text { perkuliahan } \\
\text { berdasarkan } \\
\text { beban tatap } \\
\text { muka }\end{array}$ & $\begin{array}{l}\text { Dosen tidak } \\
\text { tetap (luar } \\
\text { biasa) memiliki } \\
\text { "keistimewaan" } \\
\text { dalam memilih } \\
\text { hari atau waktu } \\
\text { jadwal } \\
\text { mengajar }\end{array}$ & $\begin{array}{l}\text { Pembukaan } \\
\text { kelas atau } \\
\text { mata kuliah } \\
\text { tidak } \\
\text { sebanding } \\
\text { dengan } \\
\text { jumlah } \\
\text { ruangan yang } \\
\text { ada }\end{array}$ & $\begin{array}{l}\text { Pada saat } \\
\text { penelitian } \\
\text { dilakukan, } \\
\text { jumlah } \\
\text { ruangan yang } \\
\text { dimiliki } \\
\text { berjumlah } 55 \\
\text { ruangan }\end{array}$ & $\begin{array}{l}\text { Slot waktu } \\
\text { perkuliahan } \\
\text { berdasarkan } \\
\text { bobot mata } \\
\text { kuliah yang } \\
\text { ditempuh } \\
\text { oleh } \\
\text { masing- } \\
\text { msaing } \\
\text { mahasiswa }\end{array}$ \\
\hline $\begin{array}{l}\text { Penelitian } \\
\text { Sekarang }\end{array}$ & $\begin{array}{l}\text { Mahasiswa } \\
\text { dibagi } \\
\text { menjadi } 2 \\
\text { yaitu kelas } \\
\text { pagi dan } \\
\text { kelas } \\
\text { malam }\end{array}$ & $\begin{array}{l}\text { Dosen Tetap } \\
\text { Matana } \\
\text { memiliki } \\
\text { kewajiban } \\
\text { mengajar } \\
\text { minimal } 9 \text { sks } \\
\text { dan dosen yang } \\
\text { memiliki } \\
\text { jabatan } \\
\text { struktural tidak }\end{array}$ & $\begin{array}{l}\text { Mata kuliah } \\
\text { umum akan } \\
\text { memiliki } \\
\text { mahasiswa } \\
\text { dari berbagai } \\
\text { program studi } \\
\text { yang berbeda } \\
\text { (kelas } \\
\text { gabungan) }\end{array}$ & $\begin{array}{l}\text { Ruangan } \\
\text { perkuliahan } \\
\text { terdiri dari } \\
\text { ruang kelas, } \\
\text { ruang lab, } \\
\text { studio dan } \\
\text { kitchen } \\
\text { (dapur) bagi } \\
\text { mahasiswa } \\
\text { jurusan }\end{array}$ & $\begin{array}{l}\text { Mahasiswa } \\
\text { untuk } \\
\text { program } \\
\text { studi } \\
\text { (jurusan) } \\
\text { arsitektur, } \\
\text { desain } \\
\text { komunikasi } \\
\text { visual dan } \\
\text { perhotelan }\end{array}$ \\
\hline
\end{tabular}




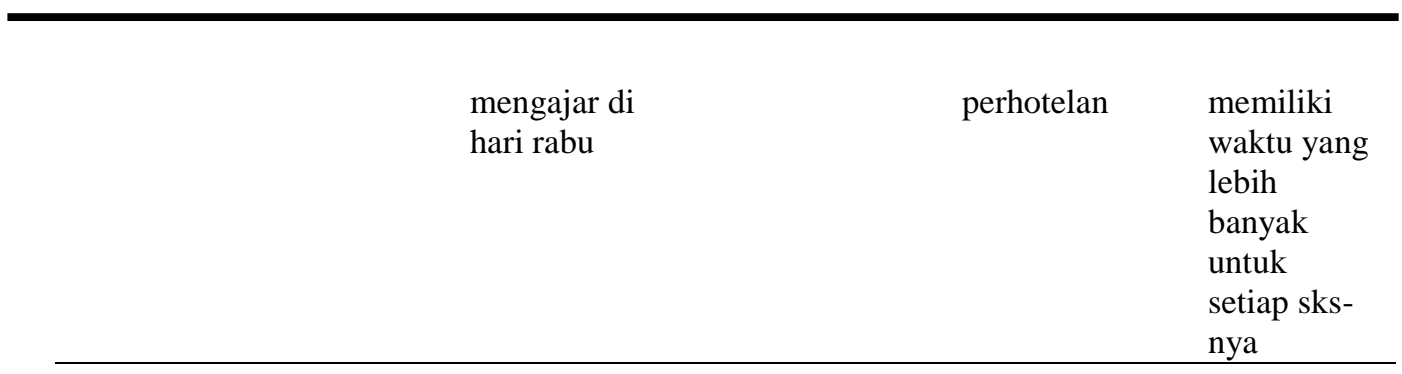

Perbedaan utama penelitian yang dilakukan oleh peneliti untuk sistem penjadwalan perkuliahan yang dilakukan di Universitas Matana akan terlihat bagaimana alokasi waktu terutama bagi dosen-dosen "khusus", di mana dosen-dosen "khusus" yang dimaksudkan disini adalah semua dosen tetap Universitas Matana yang memiliki jabatan structural mulai dari Kepala Program Studi, Dekan dan Wakil Rektor. Di mana hal tersebut telah dituliskan pada Tabel 1, bahwa semua dosen yang memiliki jabatan struktural tidak mengajar di hari rabu dan kemudian memiliki beban minimal jumlah sks mengajar yang berbeda dengan para dosen yang tidak memiliki jabatan struktural. Kemudian perbedaan yang ke-2 adalah alokasi slot waktu yang digunakan di Universitas Matana terutama bagi para mahasiswa program studi Arsitektur, Desain Komunikasi Visual dan Perhotelan. Dimana jumlah waktu untuk semua mata kuliah praktikum akan berbeda dengan jumlah waktu untuk mata kuliah non-praktikum. Di mana jumlah waktu untuk 1 sks mata kuliah praktikum adalah 100 menit ( 2 kali waktu sks normal). Kedua hal inilah yang menjadi pembeda dalam hal pengalokasian waktu perkuliahan yang berjalan di Universitas Matana, sehingga membuat sistem yang diusulkan pada penelitian ini hatus dapat mengakomodir kebutuhan-kebutuhan (hard constraints) tersebut agar penjadwalan perkuliahan dapat berjalan dengan baik dan menghindari terjadinya bentrokan jadwal mata kuliah yang satu dengan yang lainnya.

\section{Skema Database SIAKAD Matana}

Pembasan sub-bab ini akan menjelaskan dan juga menampilkan struktur dari beberapa tabel yang akan digunakan pada SIAKAD Matana, terutama tabel-tabel yang digunakan secara langsung pada penyusunan dan pembuatan jadwal mata kuliah yang akan digunakan pada saat mahasiswa akan melakukan pengisian KRS menjelang perkuliahan pada semester baru. Di mana tidak semua tabel akan ditampilkan dan dijelaskan pada sub-bab ini, hal tersebut dikarenakan informasi tabel pada SIAKAD Matana merupakan hal yang bersifat "privacy" dan sesungguhnya tidak dapat ditampilkan pada publik terkait dengan kerahasiaan dan juga keamanan data pada database server. Semua informasi yang ditampilkan pada tabel digunakan untuk keperluan penelitian dan tidak bersifat permanen, karena struktur tabel dan juga record yang ditampilkan sudah dimodifikasi oleh para peneliti sebelum ditampilkan dalam penulisan dokumen jurnal ini dibuat dan ditulis. Di mana struktur tabel yang akan digunakan adalah tabel mahasiswa, tabel dosen, tabel jadwal dosen, tabel krs, tabel mata kuliah, tabel program studi, tabel ruangan, tabel staff, tabel tahun akademik dan tabel user.

Tabel-tabel yang telah disebutkan dan dijelaskan diatas (10 tabel), jika digambarkan dalam bentuk skema diagram database akan memiliki tampilan sebagai berikut ini: 


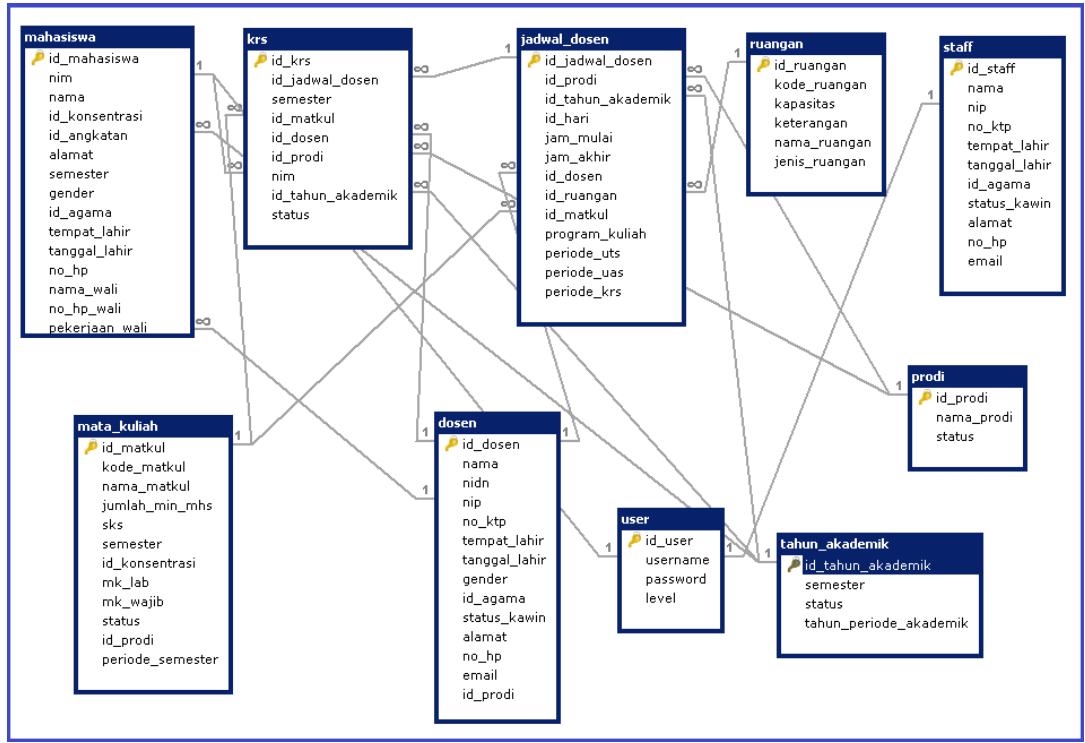

Gambar 1. Diagram Skema Database SIAKAD Matana

Pembahasan berikutnya setelah pembahasan mengenai struktur database beserta dengan beberapa tabel yang digunakan pada SIAKAD Matana adalah mengenai hasil tampilan output dari aplikasi SIAKAD Matana yang berupa halaman website (intranet) SIAKAD Matana. Berikut ini adalah beberapa halaman web yang akan dijelaskan secara singkat dalam penulisan dokumen jurnal ini:

1. Halaman utama admin, dimana halaman ini akan menampilkan menu-menu yang terdapat pada aplikasi SIAKAD Matana yaitu menu Home, menu profile, menu perkuliahan yang memiliki 5 sub menu (request dosen, cetak khs, periode pengisian nilai, periode pengisian KRS, mahasiswa submit KRS), menu master data yang memiliki 10 sub menu (data agama, data mahasiswa, data dosen, data mata kuliah, data nilai, tahun akademik, data ruangan, data program studi, data staff dan data keuangan) dan menu terakhir adalah menu logout.

2. Menu halaman request dosen yang akan digunakan untuk meng-input-kan data jadwal dosen mengajar berdasarkan permintaan dari para dosen (dosen tetap dan dosen tidak tetap) yang akan mengajar di semester berikutnya.

3. Menu halaman mahasiswa submit KRS merupakan halaman yang digunakan oleh para mahasiswa Matana untuk memilih mata kuliah yang ingin diambil pada semester berikutnya, dimana daftar mata kuliah yang ditampilkan adalah mata kuliah sesuai dengan periode semester mata kuliah tersebut dibuka (semester ganjil atau genap). Kemudian pada halaman ini juga terdapat fungsi yang digunakan untuk memeriksa jumlah maksimal SKS yang dapat diambil oleh masing-masing mahasiswa berdasarkan nilai IPS (Indeks Prestasi Semester) terakhir pada semester sebelumnya.

Tampilan output dari halaman utama backend superadmin SIAKAD Matana setelah berhasil melakukan login adalah sebagai berikut: 


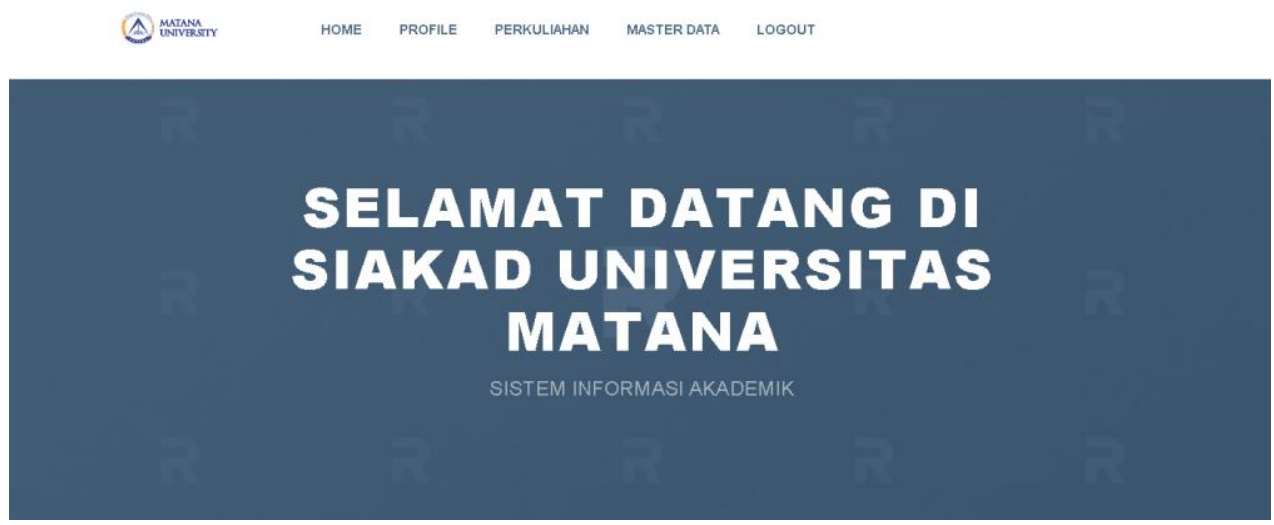

Gambar 2. Halaman Utama SIAKAD Matana

Halaman request dosen yang telah dijelaskan secara singkat sebelumnya, di mana halaman ini akan digunakan oleh para staf BPAP yang akan digunakan untuk menginputkan data jadwal mengajar dosen (tetap dan tidak tetap) berdasarkan permintaan (request) para dosen kepada kepala program studi masing-masing. Berikut ini adalah hasil tampilan output dari halaman request waktu dosen:

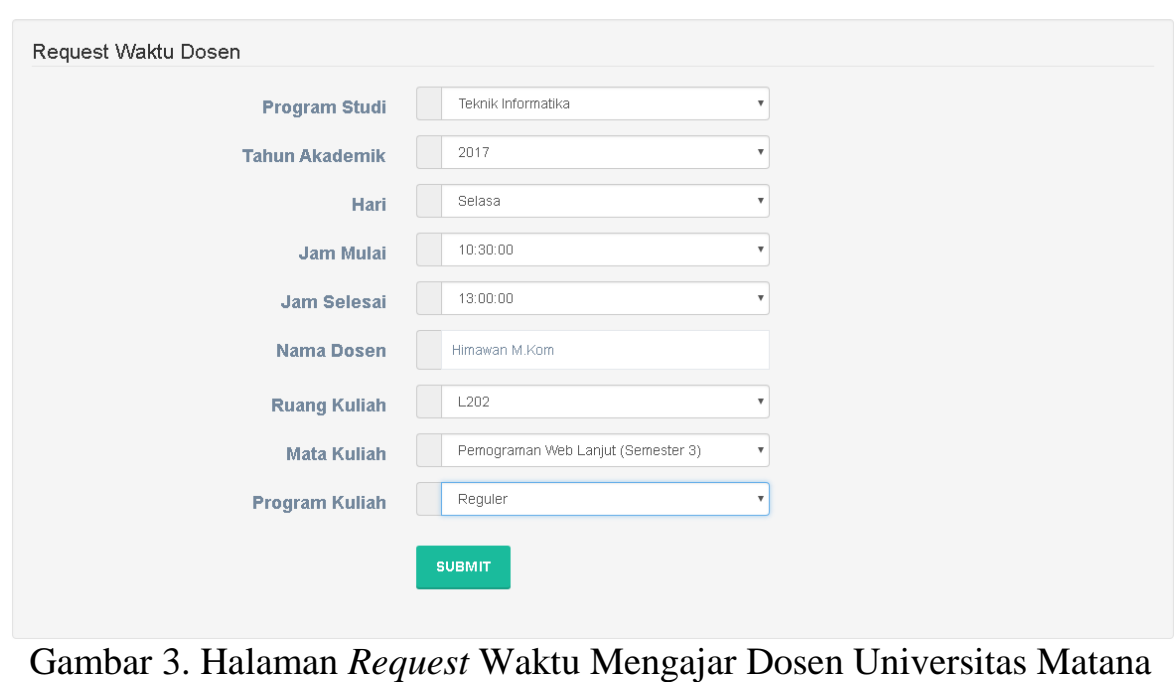

Halaman lihat jadwal mata kuliah yang ditampilkan berikut ini merupakan halaman utama (inti) dari pembahasan dokumen jurnal ini, hal tersebut dikarenakan pada halaman ini digunakan untuk menampilkan daftar mata kuliah yang dapat dipilih oleh setiap mahasiswa Matana pada saat melakukan pengisian KRS. Pada halaman ini juga optimasi query $S Q L$ digunakan untuk menampilkan daftar mata kuliah dan pada saat proses penyimpanan data-data mata kuliah yang telah dipilih oleh para mahasiswa ke dalam database server. 


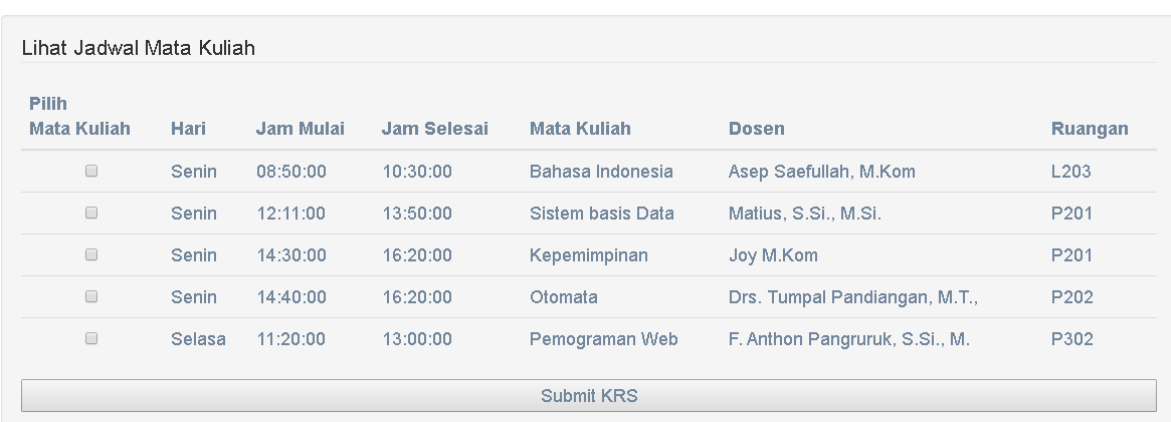

Gambar 4. Halaman Web Pemilihan Jadwal Mata Kuliah

Berikut ini adalah perintah SQL asli yang digunakan untuk menampilkan daftar mata kuliah yang ditawarkan atau dibuka pada semester berikutnya, di mana perintah SQL yang ditampilkan berikut belum diringkas menggunakan tabel alias.

SELECT hari.nama_hari, jadwal_dosen.jam_mulai, jadwal_dosen.jam_akhir, mata_kuliah.nama_matkul, dosen.nama,

ruangan.nama_ruangan FROM krs INNER JOIN jadwal_dosen ON krs.id_jadwal_dosen = jadwal_dosen.id_jadwal_dosen

INNER JOIN hari ON jadwal_dosen.id_hari = hari.id_hari

INNER JOIN mata_kuliah ON krs.id_matkul = mata_kuliah.id_matkul

INNER JOIN ruangan ON jadwal_dosen.id_ruangan = ruangan.id_ruangan

INNER JOIN dosen ON krs.id_dosen = dosen.id_dosen

WHERE krs.nim = "13110006" AND krs.id_tahun_akademik = "2";

Berikut ini adalah perbandingan penulisan perintah SQL yang telah ditulis ulang menggunakan tabel alias, di mana penggunaan tabel alias digunakan untuk mempersingkat penulisan query SQL yang bertujuan untuk mempercepat waktu eksekusi query $S Q L$ pada database server $M y S Q L$.

SELECT c.nama_hari, b.jam_mulai, b.jam_akhir, d.nama_matkul,
f.nama,e.nama_ruangan
FROM krs a INNER JOIN jadwal_dosen b ON a.id_jadwal_dosen =
b.id_jadwal_dosen INNER JOIN hari c ON b.id_hari = c.id_hari
INNER JOIN mata_kuliah d ON a.id_matkul = d.id_matkul
INNER JOIN ruangan e ON b.id_ruangan = e.id_ruangan
INNER JOIN dosen f ON a.id_dosen = f.id_dosen
WHERE a.nim = "13110006" AND a.id_tahun_akademik = "2";

Pada saat periode sibuk, pengisian KRS dapat dilakukan oleh banyak mahasiswa pada waktu yang hampir bersamaan dan hal ini akan membuat beban lalu lintas (traffic) koneksi jaringan server akan bertambah. Oleh karena itu penggunaan optimasi query pada saat daftar mata kuliah ditampilkan dan dipilih oleh para mahasiswa menjadi penting, dengan demikian pengisian KRS dapat dilakukan dengan lebih cepat dan tidak membebani kinerja server secara berlebihan. Hal tersebut akan diperlihatkan pada tabel perbandingan waktu akses (dalam detik) berikut, yaitu halaman-halaman web SIAKAD Matana yang menggunakan optimasi Query $S Q L$ dengan yang tidak menggunakan optimasi Query SQL. 
Tabel 2. Perbandingan Waktu Akses Halaman SIAKAD Matana

\begin{tabular}{lccc}
\hline \multicolumn{1}{c}{ Nama halaman } & $\begin{array}{l}\text { Jumlah } \text { user yang } \\
\text { mengakses }\end{array}$ & $\begin{array}{l}\text { Waktu load tanpa } \\
\text { optimasi query } \\
\text { SQL }\end{array}$ & $\begin{array}{l}\text { Waktu load } \\
\text { dengan optimasi } \\
\text { query } \boldsymbol{S Q L}\end{array}$ \\
\hline view jadwal kuliah & 70 & 7,380 & 3,754 \\
view krs & 70 & 5,549 & 4,965 \\
cetak krs & 70 & 8,564 & 8,265 \\
\hline
\end{tabular}

Berikut ini adalah grafik perbandingan kecepatan waktu akses pada 3 halaman yang dijadikan sebagai contoh penggunaan optimasi query, terutama pada saat pengambilan dan menampilkan data-data (record) yang ada pada database server SIAKAD Matana.

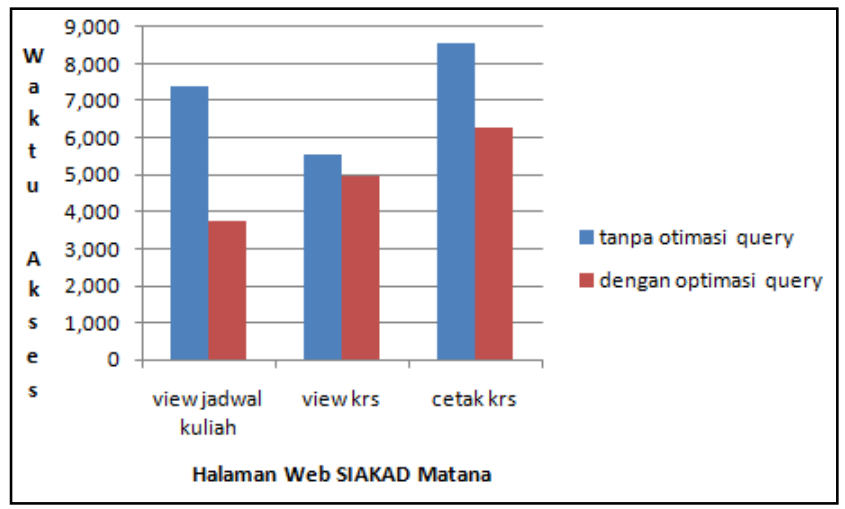

Gambar 5. Grafik Perbandingan Waktu Akses Penggunaan Optimasi Query SQL

\section{PENUTUP}

\section{Simpulan}

Penggunaan sistem informasi akademik (SIAKAD) terutama pada bagian penjadwalan mata kuliah dan pengisian KRS merupakan hal yang sangat penting untuk dapat segera digunakan dan diimplementasikan pada sebuah perguruan tinggi dan hal tersebut juga berlaku untuk Universitas Matana. Dengan adanya SIAKAD, maka semua kegiatan yang bersifat akademik dapat menjadi lebih teratur dan juga terkontrol dengan baik, pengisian KRS oleh para mahasiswa dapat dilakukan secara tepat waktu dan penyusunan jadwal perkuliahan oleh para masing-masing kepala program studi dapat menjadi lebih cepat. Para staff BPAP juga menjadi sangat terbantu dalam hal pendataan pengisian KRS yang telah dilakukan oleh para mahasiswa, kemudian meminimalkan penggunaan form fisik KRS yang akan berpengaruh pada pengurangan atau penghematan biaya pencetakan form KRS. Terakhir adalah benturan jadwal mata kuliah dapat dihindari dari awal pada saat penyusunan jadwal perkuliahan untuk semua program studi yang ada di Universitas Matana.

\section{Saran}

Penelitian dan penulisan dokumen jurnal mengenai sistem penjadwalan perkuliahan yang dilakukan oleh peneliti juga tak luput dari berbagai kekurangan atau kelemahan yang ada di dalamnya, oleh karena itu berbagai upaya perlu dilakukan untuk 
meningkatkan kualitas penelitian ini di waktu yang akan datang, di mana upaya-upaya tersebut akan dituliskan pada poin-poin berikut:

1. Sistem penjadwalan perkuliahan yang dibahas pada penulisan jurnal ini hanya berfokus pada penjadwalan perkuliahan pada semester berikutnya atau kegiatan perkuliahan yang bersifat sehari-hari. Namun pada kenyataannya kegiatan perkuliahan memiliki dinamika yang kompleks, contohnya: bagaimana penyusunan jadwal untuk kuliah pengganti jika ruangan yang digunakan terbatas?. Kemudian, bagaimana juga penyusunan jadwal untuk penggunaan ruangan kelas yang diperuntukkan untuk semua kegiatan yang diadakan diluar dari jadwal perkuliahan normal atau yang telah ditentukan sebelumnya?. Oleh karena itu SIAKAD yang ada dan telah diimplementasikan masih perlu di-update untuk menyesuaikan dengan keadaan yang ada sehingga sistem juga menjadi lebih fleksibel dan dinamis.

2. SIAKAD Matana belum memiliki "restriction" atau batasan dalam hal batas waktu pengisian KRS, dimana pihak manajemen kampus masih memberikan toleransi kepada mahasiswa untuk melakukan pengisian KRS. Diharapkan dengan adanya fitur batas waktu tersebut, walaupun sepertinya terlihat kejam namun akan menciptakan keteraturan dan sikap disiplin kepada para mahasiswa. Karena pengisian KRS yang terlambat dan jika dilakukan oleh banyak mahasiswa, maka akan menghambat kegiatan-kegiatan yang lainnya.

3. Perlu adanya fitur absensi baik oleh para mahasiswa maupun dosen yang digunakan sebelum atau pada saat kegiatan perkuliahan (mengajar) di kelas dimulai, di mana fitur absen ini akan sangat berguna untuk mengontrol dan monitoring waktu presensi para mahasiswa dan juga dosen. Selain itu juga berguna untuk meminimalkan tindak kecurangan dalam hal absensi.

\section{DAFTAR PUSTAKA}

Firdaus. (2017). Implementasi Penjadwalan Kuliah Job Shop Dengan Perancangan Jadwal Kuliah Menggunakan Constraints Programming. Jurnal \& Penelitian Teknik Informatika, Vol.1 No.2, hlm. 32-39.

Suhartono, E. (2015). Optimasi Penjadwalan Mata Kuliah Dengan Algoritma Genetika. Jurnal Ilmiah INFOKAM, Vol.11 No.2, hlm.132-146.

Syarif, A. C., \& Gunawan, F. H. (2014). Penjadwalan Mata Kuliah Dengan Perampingan Algoritma Evolusi dan Pembobotan Distribusi Beban Kuliah. Jurnal TEMATIKA, Vol.2 No.2, hlm. 81-94.

Sunarni, T., Bendi, R. K. J., \& Alfian, A. (2017). Optimasi Penjadwalan Mata Kuliah Menggunakan Pewarnaan Graf. Prosiding SNTI dan SATELIT, Malang, Indonesia, hlm. E-48-53.

Qashlim, A., \& Assidiq, M. (2016). Penerapan Algoritma Genetika Untuk Sistem Penjadwalan Kuliah. Jurnal Ilmiah Ilmu Komputer, Vol.2 No.1.

Setyaningsih, A. F. (2014). System Application of Genetic Algorithm for Scheduling Optimization Study Using Java. Journal of Proceeding Series (IPTEK), Vol.1, hlm.73-76.

Indrayana, I. N. E., Wirasyanti, N. M., \& Sudiartha, I. K. G. (2017). Heuristic Query Optimization for Query Multiple Table and Multiple Clause on Mobile Finance Application. The $2^{\text {nd }}$ International Joint Conference on Science and Technology (IJCST) (Hal. 1-9). Nusa Dua Bali, Indonesia : IOP Publising. doi: 10.1088/17426596/953/1/012049.

Olmo, S. A., Sànchez, E. L., Rosado, G. D., Medina. F. E., \& Piattini, M. (2016). Applying the Action Research Method to Develop a Methodology to Reduce the Installation and Maintanance Times of Information Security Management Systems. 